\title{
Modern neurooncology - the development of the field and the possibilities of glioma therapy in Warsaw - a neurosurgical perspective
}

\section{Bartosz Czapski, Adam Warzecha, Wojciech Górecki, Tomasz Wójcikiewicz and Mirosław Ząbek}

\section{ABSTRACT}

This article is devoted to discussing the possibility of treating malignant brain tumors in the Mazovia region. The difficult clinical problem confronted by doctors and scientists is discussed in relation to the complex nature of gliomas. The current state-of-the-art treatment along with its limitations is subjected to discussion. The opportunities available to Mazovian doctors, which can be used to significantly prolong and improve the quality of patients' lives, are presented in detail. Finally, the paper presents the wide range of possibilities for scientific cooperation and the directions it should take in order to learn more about the genesis of brain cancer and make it curable.

Key words: treating malignant brain tumors, genesis of brain cancer, Mazovia

\section{Introduction}

Brain tumors account for about $2 \%$ of cancer incidence in Poland and in 1980-2010 their number has doubled [Onkologia.org.pl 2017]. They can be divided into metastatic tumors, that istumors of another organ, the cells of which have entered the brain, and primary tumors, i.e. ones that arise directly from nervous tissue. Gliomas are tumors that derive from glial cells which make up the stroma of the brain. Gliomas account for $24.7 \%$ of all brain tumors, including $74.6 \%$ of malignant brain tumors. Glioblastoma, the most malignant glioma, accounts for $55.4 \%$ of gliomas and represents the biggest therapeutic challenge. The incidence of glioblastoma is approximately 3.20 per 100,000 , is relatively higher among men (7.75 per 100,000) than women (5.60 per 100,000) and increases with age, reaching the first peak at the age of 35-44 and the second at 75-84 [Ostrom et al. 2014; Ostrom et al. 2016].

After a glioma of the brain is diagnosed, the most important factors with a documented effect on survival are histological malignancy and factors such as age at the time of diagnosis, the degree of patient autonomy and efficiency (Karnofsky Performace Scale), and the extent of surgical treatment [Bauchet et al. 2010]. Benign gliomas, which are dominant in children, are characterized by a very mild course and a mean 5 -year survival rate of $81-97 \%$. On the 
other hand, the most malignant brain tumor, glioblastoma, is very aggressive and only about $2 \%$ of patients survive for more than 5 years [Sant et al. 2011].

In spite of the great efforts of both clinicians and scientists, the prognosis for patients with glioblastoma remains unchanged since 2000 when a new therapy was introduced in the form of a new drug - Temozolomide. In 2005, the knowledge of the complex glioblastoma problem was systematized and standardized and multimodal malignant glioma therapy was introduced, based on maximal surgical tumor excision followed by radiochemotherapy. This allowed for a median survival rate of 14.6 months to be achieved (compared to about 3 months in the absence of treatment) [Stupp et al. 2005].

\section{Surgical management}

Neurosurgical treatment of gliomas is very difficult due to the complexity of the disease. Malignant glial tumors, especially glioblastoma, are often beyond the reach of even the most skilled neurosurgeon because of their infiltrating nature. An additional difficulty is the specificity of brain tissue. Unlike in the case of "standard" oncological surgery, in the case of brain tumors, it is difficult to implement the "margins of oncological purity", i.e. removal of diseased tissue with a margin of healthy, free of disease tissue which determines the complete removal of the tumor. Due to the high local malignancy of the tumor and its strong penetration into the brain, we can not respect the above principles during neurosurgical procedures because there are no clear boundaries between healthy tissue and the tumor and there is a possibility of irreversible damage to parts of the brain important for proper functioning.

\section{Neuroimaging}

In Mazovia, patients have access to state-of-the-art technologies that increase the safety of surgical procedures and increase the potential for surgical treatment of brain tumors. The key element of this system is the availability of modern neuroimaging apparatus, mainly magnetic resonance imaging. Whereas the gold standard diagnostic criteria for central nervous system disorders, including brain tumors, is imaging with a 1.5T magnetic resonance imaging, patients have the opportunity to use 3T magnetic resonance imaging to allow for more accurate brain tumor diagnostics [Matsusue, Ogawa 2007]. We are now able to accurately predict the exact location of the functionally important parts of the brain, for example, centers responsible for the production and the understanding of speech or movement initiation, and to trace the nerve pathways from these centers to our body [Krautmacher et al. 2005]. This is used to plan the surgery in such a way that the removal of the tumor does not damage the marked structures. Such an approach guarantees good results of surgical treatment and the possibility of removing diseased tissue as much as possible within the limits set before surgery. 
Another use of 3T magnetic resonance imaging is intraoperative imaging, which consists of performing a study during an operation [Ginat et al. 2013]. Thanks to this technique we can depict the "hidden" residual tumor part and expand the scope of surgery accordingly [Schulder, Liang 2012]. Combined with the techniques used in our hospital to wake the patient during surgery and map eloquent or specific brain areas and functions (e.g. speech or movement with the right part of the body) [Huberfeld et al. 2017] and intraoperative tumor staining with fluorescein [Catapano et al. 2017], complete glioma resection is up to $96 \%$ of cases. Without the use of advanced imaging techniques, total tumor removal was achieved on average only in $68 \%$ of patients [Senft et al. 2011].

\section{Pushing the frontiers of knowledge}

\section{Basic science}

In the Mazovia region, a multicenter research cooperation has been established in the field of neurooncology concerning mainly the pathogenesis and development of new therapeutic options for brain gliomas. Currently, practically all neurosurgery departments located in the Polish capital take an active part in research conducted at the Marcel Nencki Institute of Experimental Biology. Our goal, apart from the purely clinical part, i.e. thorough documentation of the patient's health status and appropriate treatment, is to deliver a small portion of the tumorin the appropriate media to the laboratory. The Laboratory of Molecular Neurobiology is conducting a series of studies on the complex genetics of gliomas in vitro as well as in vivo using animal models, including diagnosis of gliomas based on circulating cell-free DNA, signaling pathways in pathogenesis of gliomas, epigenetic therapies in neurooncology, development of selective antitumor immunomodulators, altogether leading to development of a novel, complex therapy of gliomas [Kaminska-lab.pl 2017].

\section{Clinical studies}

We are proud to announce that we have started an international clinical trial in collaboration with the leading research center from the United States - the University of California, San Francisco where a well-established anti-tumor drug, effective in the fight against glioblastomas, irinotecan is beeing used in a novel way [Vredenburgh et al. 2008]. So far, this drug has been administered orally and has been shown to result in a statistically significant prolongation of life but the effect was still unsatisfactory. The main problems of chemotherapy are its systemic complications and the overcoming of the "blood-brain barrier". The cells of the blood vessels and brain are separated from one another by means of close links between themselves. Any transport of both nutrients and drugs is based on active transport by complex cellular mechanisms. With the use of diffusion-based drug delivery 
technology, we will be able to bypass the blood-brain barrier with a specially designed needle and administer the drug by slow infusion so that it can diffuse into the tumor. Current experience on animal models is very promising - life expectancy has been prolonged and, in some cases, tumor disappearance has been noted [Bankiewicz Laboratory ... 2017].

\section{Conclusions}

In the Mazovia region, patients have access to the most advanced therapeutic modalities for gliomas of the brain, particularly in terms of neurosurgery. Access to the newest technology translates into quality of treatment and improves both the quality and length of glioblastoma patients' lives in a statistically significant manner. Apart from therapeutic possibilities, Mazovia can be proud of very active research centers, which are internationally recognized and respected. Thanks to well-planned activities and good communication on the physician-scientist line, we can hope for a successful solution to the challenges posed by brain cancer.

\section{References}

Bankiewicz Laboratory for Translational Neuroscience Research, 2017, Neurosurgery.ucsf.edu. Retrieved 11 June 2017, from http://neurosurgery.ucsf.edu/bankiewicz/brain_cancer.html.

Bauchet L., Mathieu-Daude H., Fabbro-Peray P., Rigau V., Fabbro M. \&Chinot O. et al., 2010, Oncological patterns of care and outcome for 952 patients with newly diagnosed glioblastoma in 2004, Neuro-Oncology, 12, 7, pp. 725-735; http://dx.doi.org/10.1093/neuonc/noq030.

Catapano G., Sgulò F., Seneca V., Lepore G., Columbano L. \& di Nuzzo G., 2017, Fluoresceinguided Surgery for High Grade Glioma Resection: an Intraoperative "Contrast-enhancer", World Neurosurgery; http://dx.doi.org/10.1016/j.wneu.2017.05.022.

Ginat D., Swearingen B., Curry W., Cahill D., Madsen J. \& Schaefer P., 2013, 3 Tesla intraoperative MRI for brain tumor surgery, Journal of Magnetic Resonance Imaging, 39, 6, pp. 1357-1365; http://dx.doi.org/10.1002/jmri.24380.

Huberfeld G., Trébuchon A., Capelle L., Badier J., Chen S., Lefaucheur J., Gavaret M., 2017, Preoperative and intraoperative neurophysiological investigations for surgical resections in functional are-as, Neurochirurgie;http://dx.doi.org/10.1016/j.neuchi.2016.10.008.

Krautmacher C., Willinek W., Tschampa H., Born M., Träber F. \&Gieseke J. et al., 2005, Brain Tumors: Full-and Half-Dose Contrast-enhanced MR Imaging at 3.0 T Compared with 1.5 T-Initial Experience, Radiology, 237, 3, pp. 1014-1019; http://dx.doi.org/10.1148/radiol.2373041672. 
Laboratory of Molecular Neurobiology, 2017, Kaminska-lab.pl. Retrieved 11 June 2017, from https://sites.google.com/site/braintumors16/.

Matsusue E., Ogawa T., 2007,Clinical applications of 3.0 T magnetic resonance system in the neuroradiological field, Brain Nerve, 59, 5, pp. 479-485; http://dx.doi.org/10.11477/ mf.1416100041.

Ostrom Q., Bauchet L., Davis F., Deltour I., Fisher J., \& Langer C. et al., 2014, The epidemiology of glioma in adults: $a$ "state of the science" review, Neuro-Oncology, 16, 7, pp. 896-913; http:// dx.doi.org/10.1093/neuonc/nou087.

Ostrom Q., Gittleman H., Xu J., Kromer C., Wolinsky Y., Kruchko C. \&Barnholtz-Sloan J., 2016, CBTRUS Statistical Report: Primary Brain and Other Central Nervous System Tumors Diagnosed in the United States in 2009-2013, Neuro-Oncology, 18,5, pp. v1-v75; http://dx.doi. org/10.1093/neuonc/now207.

Sant M., Minicozzi P., Lagorio S., Børge Johannesen T., Marcos-Gragera R. \&Francisci S., 2011,Survival of European patients with central nervous system tumors, International Journal of Cancer, 131, 1, pp. 173-185; http://dx.doi.org/10.1002/ijc.26335.

Schulder M., Liang D., 2012, The role of intraoperative magnetic resonance imaging in glioma surgery,Surgical Neurology International, 3, 5, p. 320; http://dx.doi.org/10.4103/21527806.103029 .

Senft C., Bink A., Franz K., Vatter H., Gasser T. \& Seifert V., 2011, Intraoperative MRI guidance and extent of resection in glioma surgery: a randomised, controlled trial, The Lancet Oncology, 12, 11, pp. 997-1003; http://dx.doi.org/10.1016/s1470-2045(11)70196-6.

Strona główna KRN, 2017. Onkologia.org.pl. Retrieved 11 June 2017, from http://onkologia.org.pl/.

Stupp R., Mason W., van den Bent M., Weller M., Fisher B. \&Taphoorn M. et al., 2005, Radiotherapy plus concomitant and adjuvant temozolomide for glioblastoma, New England Journal of Medicine, 352, 10, pp. 987-996; http://dx.doi.org/10.1056/nejmoa043330.

Vredenburgh J., Desjardins A., Reardon D. \& Friedman H., 2008, Experience with irinotecan for the treatment of malignant glioma, Neuro-Oncology, 11, 1, pp. 80-91;http://dx.doi. org/10.1215/15228517-2008-075. 


\section{WSPÓŁCZESNA NEUROONKOLOGIA - ROZWÓJ DZIEDZINY I MOŻLIWOŚCI TERAPII GLEJAKOWEJ W WARSZAWIE - PERSPEKTYWA NEUROCHIRURGICZNA}

\section{STRESZCZENIE}

Artykuł ten poświęcony jest omówieniu możliwości leczenia złośliwych nowotworów mózgu w województwie mazowieckim. Omawiany jest złożony problem kliniczny, dotyczący skomplikowanej natury guzów glejopochodnych. Obecny schemat leczenia jest poddawany pod dyskusję wraz z jego ograniczeniami. Przedstawiane są możliwości, z których mogą korzystać lekarze mazowieckich szpitali, mające istotny wpływ na zwiększenie jakości, jak i przedłużenia życia pacjentów. Na zakończenie przedstawione są szerokie możliwości współpracy naukowej oraz jej kierunki mające na celu poznanie genezy nowotworów mózgu, aby w przyszłości uczynić je uleczalnymi.

Słowa kluczowe: leczenie złośliwych nowotworów mózgu, genezy nowotworów mózgu, województwo mazowieckie 
Mirosław Ząbek, Associate professor - Head of the Neurosurgery and Neurotrauma Department of the Medical Center of Postgraduate Education in Warsaw - academic instructor - supervised numerous doctoral dissertations and oversaw neurosurgical medical speciality of young doctors in Poland. A graduate of the Warsaw Medical Academy. He attended European Neurosurgery Training (1987-1991) as well as individual neurosurgical training internships in Finland, Germany, Sweden, Italy, Spain, France, United States, Belgium and Japan.

Mirosław Ząbek, dr hab. n. med., prof. CMKP - Kierownik Kliniki Neurochirurgii i Urazów Układu Nerwowego Centrum Medycznego Kształcenia Podyplomowego w Warszawie oraz nauczyciel akademicki - wyspecjalizował oraz przeprowadził przewody doktorskie wielu lekarzy. Absolwent Warszawskiej Akademii Medycznej. Odbył Europejskie Szkolenie Neurochirurgiczne (1987-1991), jak również indywidualne neurochirurgiczne staże szkoleniowe w Finlandii, Niemczech, Szwecji, Włoszech, Hiszpanii, Francji, Stanach Zjednoczonych, Belgii i Japonii.

Adam Warzecha, MD, PhD - Senior assistant and lecturer at the Neurosurgery and Neurotrauma Department of the Medical Center of Postgraduate Education in Warsaw, neurosurgeon.

Adam Warzecha, dr n. med. - starszy asystent oraz wykładowca Kliniki Neurochirurgii i Urazów Układu Nerwowego Centrum Medycznego Kształcenia Podyplomowego w Warszawie, specjalista neurochirug.

Tomasz Wójcikiewicz, MD - Senior assistant at the Neurosurgery and Neurotrauma Department of the Medical Center of Postgraduate Education in Warsaw, neurosurgeon.

Tomasz Wójcikiewicz, lek. - starszy asystent Kliniki Neurochirurgii i Urazów Układu Nerwowego Centrum Medycznego Kształcenia Podyplomowego w Warszawie, specjalista neurochirug.

Wojciech Górecki, MD - Assistant at the Neurosurgery and Neurotrauma Department of the Medical Center of Postgraduate Education in Warsaw, neurosurgeon.

Wojciech Górecki, lek. - asystent Kliniki Neurochirurgii i Urazów Układu Nerwowego Centrum Medycznego Kształcenia Podyplomowego w Warszawie, specjalista neurochirug.

Bartosz Czapski, MD - Resident of neurosurgery at the Neurosurgery and Neurotrauma Department of the Medical Center of Postgraduate Education in Warsaw, PhD student at the Postgraduate School of Molecular Medicine of Medical Warsaw University Bartosz Czapski, lek. - rezydent neurochirurgii Kliniki Neurochirurgii i Urazów Układu Nerwowego Centrum Medycznego Kształcenia Podyplomowego w Warszawie, doktorant Studium Medycyny Molekularnej Warszawskiego Uniwersytetu Medycznego. 